\title{
Efforts to increase participation of beginner voters in the general election of 2019
}

\author{
D. Sukriono* \\ Universitas Negeri Malang, Malang, Indonesia
}

\begin{abstract}
This article describes the efforts made by the government to increase the participation of beginner voters in the simultaneous general election held in 2019. The study uses a qualitative approach with a descriptive type. Data was collected through interviews, observations, and documentation. Data was analyzed using an interactive model with three activities flowing together, namely reducing data, presenting data and drawing conclusions. The problems faced by beginner voters as one of the determinants of the success of the election are very diverse, one of which is the lack of information regarding the implementation of elections and the problem of administrative requirements that must be met by beginner voters. Efforts made by the General Election Commission $(K P U)$ to increase the participation of beginner voters include socialization, optimization of General Election Commission social media, the formation of democratic volunteers, and providing an election smart home. This is also a major factor that can affect the level of voter turnout in simultaneous elections.
\end{abstract}

Keywords: beginner voters, participation, simultaneous elections, socialization

\section{INTRODUCTION}

The election implies the implementation of governance mechanisms in an orderly, orderly and peaceful manner and the birth of a society that can respect the opinions of others. Besides that, a society that has a high level of criticism will be born, in the sense that it is selective or usually chooses the best according to its beliefs (KPU, 2015).

However, in reality there are still people who are ignorant of the electoral process and do not even participate in elections that are held (white group/abstentions). Based on the Central Election Commission (KPU) notes, the abstention rate from year to year is increasing, although in 2014 there was a slight increase. The data shows that abstentions in consecutive elections since 1999, 2004, 2009 and 2014 reached 6.70\%, 15.93\%, 29.01\% and 24.89\% (Irawan, 2014).

Elections are held to elect members of the Parliament, Regional Representative Council, President and Vice President and Regional Parliament. This is in accordance with Article 22E paragraph (2) of the 1945 Constitution of the Republic of Indonesia: "General elections are held to elect members of the parliament, Regional Representative Council, the President and Vice-President, and the Regional Parliament".

Decision of the Constitutional Court Number 14/PUU-XI/2013 related to the implementation of the election of President and Vice President (hereinafter referred to as the Presidential Election) and the Election of Members of the Parliament, Regional Representative Council, Regional Parliament (hereinafter referred to as legislative election), which have been carried out simultaneously, have brought a new nuance in the democratic process in Indonesia (Rapita, 2014).

${ }^{*}$ Corresponding Author 
Law No. 7 of 2017 concerning general elections provides guarantees for beginner voters who, on 17 April 2019, are at least 17 years old to be able to exercise their voting rights in the 2019 elections. Of course, if we count the number, it is large compared to the previous elections. Around 196.5 million voters in the 2019 elections, and 7.4 percent of them or around 14 million voters are young people who have the right to vote for the first time (Soesatyo, 2019). Whereas the Ministry of Home Affairs recorded about 5 million beginner turnouts in the 2019 elections. This data was obtained from the Potential Electoral Population Register (DP4). Delivered by the Director General of Population and Civil Registration of the Ministry of Home Affairs, Fakrulloh (2018), that in the DP4 there are beginner voters who will be 17 years old from 1 January 2018 to 17 April 2019 with $5,035,887$ inhabitants.

\section{METHODS}

The study uses a qualitative approach with a descriptive type, namely by describing the entirety of the efforts made by the KPU to increase the participation of beginner voters. Specifically, the study was conducted in Malang City. Research locations in the KPU Malang City, Malang City Election Supervisory Board and Malang City community were used as sampling. The reason is that Malang City in 2019 is one of the participants in the regional head elections which is organized according to the simultaneous election agenda. In addition, seeing several previous regional head election periods the community participation rate has decreased. Primary and secondary data was collected through interviews, observations, and documentation (Moleong, 2007). The data obtained was then analyzed using an interactive model with three activities flowing together, namely reducing data, presenting data and drawing conclusions (Miles \& Huberman, 2009).

\section{RESULTS AND DISCUSSION}

\subsection{Problems of beginner voters in 2019 concurrent elections}

Beginner voters according to Wardhani (2018), are voters who have different natures and characters, backgrounds, experience and challenges with voters in the previous generation. Most of them are students, have good economic status, and generally live-in urban areas or surrounding areas. This group is very touched by the advancement of information technology, they use the tools of sophisticated technology well, ranging from cell phones, laptops, tablets and various other gadgets. They are also very fluent in using social media facilities and networks, such as Twitter, Facebook, LinkedIn, and so on.

In general, the problems that occur in the beginner voter in the 2019 simultaneous elections include: first, the first voter has not done the recording and printing of the electronic identity card (they do not have electronic identity card). Beginner voters, especially students, still haven't done the recording and printing of electronic identity cards which are used as one of the requirements to become a voter. The number of first-time voters (aged 17 years to 21 years) was 10,310 people, while the number of voter list in Malang City in the 2019 simultaneous elections was 263,185 people (Asminingtyas, 2019); Second, the beginner voters can fully use their voting rights even though administratively they can work. The requirements for recording, issuing and granting electronic identity cards can only be done on the day when the population is 17 years old; Third, in Law Number 7 of 2017 concerning Elections, an additional Voter List (DPTb) is regulated. Or, voters who have registered in the voter list at the polling station who due to certain circumstances the voters cannot use their rights to vote at the polling station where they registered and vote at another polling station. Beginner voters especially do not understand the procedure of moving the region selection correctly; Fourth, beginner voters are less interested in election activities. The proof is that many of them do not understand the electoral process and there are even some who do not know and care about the 2019 elections. 


\subsection{Participation of beginner voters in 2019 concurrent elections}

Political participation according to Closky inside Budiardjo (2008) is a voluntary activity of community members through which they take part in the process of electing the authorities and directly or indirectly in the general policy formation process. An important aspect of democracy is political participation. Political participation is a hallmark of political modernization.

According to Conyers (1994), there are three main reasons why community participation has very important properties. First, community participation is a useful tool to obtain information about the conditions, needs and attitudes of the local community, which are without its presence in development programs and projects will fail. Second, the community will trust the development project or program more if it feels involved in the process preparation and planning, because they will know more about the ins and outs of the project and will have a sense of ownership of the project. Third, the assumption arises that is a democratic right if the community is involved in community development themselves.

Max Weber in Damsar (2010), the reason people do political activity is because: first, for rational reasons and values, namely reasons which are based on rational acceptance of a values group. Second, emotional reasons are effective, that is, the reason is based on hateful or voluntary feelings towards ideas, organizations, parties or individuals. Third, traditional reasons, namely reasons which are based on acceptance of individuals or norms of behavior in certain traditions of a group social. Fourth, rational reasons are instrumental, namely the reasons for which based on the calculation of profit and loss economically.

Based on the data obtained, the level of voter participation in Malang in the 2019 simultaneous elections can be seen in the following table 1 .

Table 1. Voter participation rate in Malang city (data obtained from General Election Commission of Malang city)

\begin{tabular}{ll}
\hline Types of General Election & Participation Level \\
\hline President and Vice President & $84,08 \%$ \\
Parliament Members & $82,21 \%$ \\
Regional Representative Council Member & $82,63 \%$ \\
Province Parliament Members & $82,21 \%$ \\
Regional Parliament Members & $81,99 \%$ \\
\hline
\end{tabular}

This level of community participation has exceeded the target of $77.5 \%$. So that it can be said that the Simultaneous Election in Malang City has been successful and successfully implemented. The high political participation of novice voters in Malang in the 2019 Election, is identical to Milbrath in Sastroatmodjo (1995), namely: (1) acceptance of political incentives, namely openness and acceptance of someone against political incentives through personal contacts, organizations and social media; (2) a person's social characteristics, namely economic status, ethnic characteristics, age, gender and religion. Although novice voters have different characteristics, there are quite a number of novice voters who are concerned and aware of their political rights in society; (3) the political system and party system in which an individual is located. Indonesia as a democracy and there is a tendency of citizens to participate in politics, namely elections; and (4) regional differences, namely environmental aspects that influence differences in the character and behavior of individuals in political participation.

While the obstacles to political participation according to Mas'oed (2008) are: (1) the bustle of daily activities because novice voters are students and workers. Novice voters between the ages of 17 to 21 years are busy working as students and this can make them reluctant to participate in politics; (2) awareness, meaning that the level of education is low or the lack of knowledge in the political field and the low socio-economic life also affects the activeness of a person in the political field; and (3) the family has a great influence on one's political activities. The family can support or even oppose the behavior of family members. 


\subsection{Efforts made by KPU to increase participation of beginner voters in 2019 concurrent elections}

James W. Vander Zanden in (Damsar, 2010) defines socialization as the process of social interaction with which people gain knowledge, attitudes, values, and essential behavior for effective participation in society. Furthermore, Dharmawan (2016) defines socialization as the process of planting or transferring habits or values and rules from one generation to another in a group or community.

Normatively general elections are held with public participation as stated in Law Number 7 of 2017 concerning General Elections, namely Chapter XVII Society Participation Article 448: (1) elections are held with public participation; (2) community participation as referred to in paragraph (1) can be done in the form of: a. election socialization; b. political education for voters; c. surveys or polls about elections; and d. quick calculation of election results; (3) the form of community participation referred to in paragraph (2) with the provisions: a. they cannot have alignments beneficial or detrimental to election contestants; $b$. they cannot interfere with the process of organizing election stages; c. they must aim to increase political participation society at large; and d. they must encourage the realization of a conducive atmosphere for holding a safe, peaceful election orderly and smoothly.

The General Election Commission issued KPU Regulation Number 10 of 2018 concerning Socialization, Voter Education, and Community Participation in the Implementation of General Elections Section 2 Implementation of Socialization, Voter Education, and Participation the community in organizing general elections is guided by the principles of: independence, honesty, legal certainty, order, public interest, openness, proportional, professionality, accountability, efficiency, effectiveness, and accessibility.

The point is according to Dharmawan (2016), the socialization conducted by KPU is considered more focused on the D-day only and lacks an awareness of the importance of the substance the election itself, which is about what, who and how quality and elections have integrity. Therefore, the socialization innovation regarding elections is very much important to do so that the election from time to time gets more quality. After all the election has become a price die as a mechanism to produce democratic government.

Efforts specifically made to increase the participation of novice voters include the Malang City General Election Commission together with the Malang City Election Supervisory Board. In particular the Malang City KPU has carried out various activities including, socialization, optimization of social media General Election Commission, the formation of democratic volunteers and providing Election Smart Houses.

\section{a. Socialization}

The General Election Commission cooperates with various parties in socialization activities. In addition, students are the right targets because they will later determine and continue the success of the democratic system in Indonesia, one of which is through their participation in elections. Some universities that have collaborated with the General Election Commission include: Malang State University, Widyagama University of Malang, Brawijaya University, UIN Maulana Malik Ibrahim, Muhammadiyah University of Malang, Malang Islamic University.

Some of the socialization activities carried out by the General Election Commission include: (1) political education and Socialization of the 2019 General Election for Beginner Voters in Schools and held in hotels, (2) making the "Malang Run Election Mbois" event in the car free day area, (3) music concert "105 Unity in Harmony", and (4) Seminar on Election Management to students of the Faculty of Social and Political Sciences, Brawijaya University.

b. Optimization of the social media General Election Commission

The General Election Commission of Malang City creates some platforms of social media accounts such as Instagram, Twitter, Garudeya TV Youtube content, and Facebook as an effort to increase 
public participation. The creation of social media accounts is one of them to reach voters who are currently a millennial generation who are close to technology. Saldana, et al (2015) revealed that one of the factors that encouraged novice voters in political participation was the use of social media, namely the internet. Gallup survey agency (2012) states that one in five people in Indonesia (20.6\%) use the internet in their lives, and today, more than half (51\%) of Indonesia's young population aged between 15-24 years have used the internet in activities. Most of this young population (96.2\%) are social media users.

Furthermore, the results of the global index were quoted from Katadata (2018) of internet users in Indonesia in the age range of 16-64 years. The largest social media platform is Youtube with a percentage of usage of $43 \%$, ranked second on Facebook with a percentage of usage of $41 \%$, then Instagram with a percentage of usage of $38 \%$.

\section{c. Democracy volunteers}

Malang City General Election Commission formed Democracy Volunteers. There are 55 (fiftyfive) people selected as Malang City who have 10 bases, namely: family base, beginner voter base, young voter base, female voter base, disability base, religious base, marginal base, community base, voter base with special needs, and an internet base.

\section{d. Election smart house}

Malang City General Election Commission also provides Election Smart House or Hamur Garuyeda in Malang City General Election Commission Office. Hamur Garudeya facilitates students to study election activities ranging from miniature elections (miniature polling stations, election simulations, steps to implement voting), how to check the permanent voter list, how to update voter data, and other matters related to election activities. Several times students or the public came to Hamur Garuyeda to ask for information about the election or just came to see the latest information. After the simultaneous election event, it was also still used by many parties, for example the guest lecturer of UIN Maulana Malik Ibrahim State Administration Department student on 3 September 2019.

\section{CONCLUSIONS}

The problems of beginner voters in the 2019 concurrent elections include: novice voters have not done the electronic identity card recording and printing; beginner voters cannot fully use their voting rights even though administratively they can work. The terms of recording, issuance and granting of electronic identity cards can only be done on the day when the population is 17 years old and while if done on election day 17 April 2019 can be considered a violation of regulations; additional voter list issues or select regional moving procedures that are not understood by prospective voters; and the lack of beginner voter understanding of elections.

The level of participation of the people of Malang in the simultaneous elections in 2019 was $82.6 \%$. This exceeds the target of $77.5 \%$. This also includes an increase in voter turnout in Malang. In particular the Malang City General Election Commission has carried out various activities to increase the participation of novice voters, among others, socialization, optimization of General Election Commission social media, the formation of democratic volunteers and providing election smart houses and many more.

\section{REFERENCES}

Budiardjo, M. 2008. Dasar-dasar ilmu politik. Jakarta: PT Gramedia Pustaka Utama.

Conyers, D. 1994. Perencanaan sosial di dunia ketiga: Suatu pengantar. Yogyakarta: Gadjah Mada University Press.

Damsar. 2010. Pengantar sosiologi politik. Jakarta: Kencana Prenada Media Group. 
Dharmawan, A. T. P. 2016. Inovasi model sosialisasi peran serta masyarakat dalam pemilu. Jurnal Wacana Politik 1(2): 12-21.

Irawan, D. 2009. Detik News, 10 Mei 2014, "Dibanding tahun 2009, angka golput pemilu lebih rendah", Retrieved from: (http://news.detik.com/read/2014/05/10/074125/2578828 /1562/ dibandingtahun-2009).

Katadata. 2018. Media yang paling sering digunakan di Indonesia. Tersedia Retrieved from: https:// databoks.katadata.co.id/datapublish/2018/02/01/media-sosial-apayang-paling-sering-digunakan-masyarak at-indonesia.

Mas'oed, M \& Collin, M. A. 2008. Perbandingan sistem politik. Yogyakarta: Gajah Mada University Press.

Miles, M. B., \& Huberman, A. M. (2007). Analisis data kualitatif: buku sumber tentang metode-metode baru. Jakarta: UI Press.

Moleong. 2007. Metodologi penelitian kualitatif, Bandung: PT Remaja Rosdakarya.

Rapita, D. D. 2014. Dasar pertimbangan hukum putusan hakim Mahkamah Konstitusi terkait pelaksanaan Pileg dan Pilpres Tahun 2014 dan 2019. Jurnal Arena Hukum UB.

Republik Indonesia. 1945. Undang-Undang Dasar Negara Republik Indonesia Tahun 1945.

Republik Indonesia. 2008. Undang-Undang Nomor 42 Tahun 2008 tentang Pemilihan Umum Presiden dan Wakil Presiden.

Republik Indonesia. 2011. Undang-Undang Nomor 15 Tahun 2011 tentang Penyelenggara Pemilihan Umum. Republik Indonesia. 2012. Undang-Undang Nomor 8 Tahun 2012 tentang Pemilihan Umum Anggota DPR, DPD dan DPRD.

Republik Indonesia. (2014). Undang-Undang Nomor 23 Tahun 2014 tentang Pemerintahan Daerah.

Republik Indonesia. 2017. Undang-Undang Nomor 7 Tahun 2017 tentang Pemilihan Umum.

Saldana, M., et al. 2015. Social media as a public space for politics: cross - national comparison of news consumption and participatory behaviors in the United States and the United Kingdom. International Journal of Communication 9: 3304-3326.

Sastroatmodjo, S. 1995. Partisipasi politik. Semarang: IKIP Semarang Press.

Wardhani, P. S. N. 2018. Partisipasi politik pemilih pemula dalam pemilu. Jurnal Pendidikan Ilmu-Ilmu Sosial 10(1): 57-62. 